\title{
PENCEGAHAN DAN PENGENDALIAN INFEKSI SILANG PADA TINDAKAN EKSTRAKSI GIGI DI RUMAH SAKIT GIGI DAN MULUT PSPDG FK UNSRAT
}

\author{
${ }^{1}$ Meilan M. Suleh \\ ${ }^{2}$ Vonny N.S. Wowor \\ ${ }^{3}$ Christy N. Mintjelungan
}

\author{
${ }^{1}$ Kandidat Skripsi Program Studi Pendidikan Dokter Gigi Fakultas Kedokteran \\ ${ }^{2}$ Program Studi Pendidikan Dokter Gigi Fakultas Kedokteran \\ Universitas Sam Ratulangi Manado \\ Email: meilanmalindasuleh@yahoo.co.id
}

\begin{abstract}
Tooth extraction is one of the high risk actions that can cause cross-infection. Prevention and control of a cross-infection is needed in tooth extraction because the field of dentistry work contacts directly with blood and saliva. This was a descriptive observational study with a cross sectional design. There were 44 samples obtained by using purposive sampling method. This study aimed to determine the prevention and control of cross infection in dental extractions at the Dental Hospital PSPDG FK Unsrat. The results showed that the prevention and control of cross-infection pre-action tooth extraction was 37.4\%. The prevention of cross infection control during dental extractions was $60.26 \%$. The prevention of cross infection control after tooth extraction was $47.16 \%$. In general, prevention and crossinfection control in dental extractions at the Dental Hospital PSDDG FK Unsrat was only done by $48.23 \%$.
\end{abstract}

Keywords: prevention and control of cross-infection, tooth extraction action

\begin{abstract}
Abstrak: Ekstraksi gigi merupakan salah satu tindakan berisiko tinggi menyebabkan terjadinya infeksi silang. Pencegahan dan pengendalian infeksi silang sangat dibutuhkan pada tindakan ekstraksi gigi, karena bidang kerja kedokteran gigi berhubungan langsung dengan darah dan saliva. Jenis penelitian ini deskritif observasional dengan desain potong lintang. Pengambilan sampel menggunakan metode purposive sampling dengan jumlah 44 sampel. Penelitian ini bertujuan untuk mengetahui pencegahan dan pengendalian infeksi silang pada tindakan ekstraksi gigi di Rumah Sakit Gigi dan Mulut PSPDG FK Unsrat. Hasil penelitian menunjukkan bahwa pencegahan dan pengendalian infeksi silang pra tindakan ekstraksi gigi dilakukan sebesar 37,4\%. Pencegahan dan pengendalian infeksi silang selama tindakan ekstraksi gigi dilakukan sebesar 60,26\%. Pencegahan dan pengendalian infeksi silang paska tindakan ekstraksi gigi dilakukan sebesar 47,16\%. Secara umum, pencegahan dan pengendalian infeksi silang pada tindakan ekstraksi gigi di RSGM PSDDG FK Unsrat hanya dilakukan sebesar 48,23\%.
\end{abstract}

Kata kunci: pencegahan dan pengendalian infeksi silang, tindakan ekstraksi gigi.

Pembangunan kesehatan pada dasarnya ditujukan untuk meningkatkan kesadaran, kemauan dan kemampuan hidup sehat bagi setiap orang untuk mewujudkan derajat kesehatan yang optimal. Derajat kesehatan yang optimal mempunyai pengaruh yang sangat besar terhadap sumber daya manusia, yang dibutuhkan untuk pembangunan. Upaya pembangunan di bidang kesehatan gigi dan mulut bukan saja 
meliputi upaya kuratif, tetapi juga meliputi upaya preventif dan promotif. Berbagai upaya ini dilakukan untuk meningkatkan pelayanan kesehatan guna mencapai tujuan akhir pembangunan kesehatan, yakni derajat kesehatan yang optimal. Salah satu upaya kuratif yang banyak dilakukan dalam bidang kesehatan gigi dan mulut, yaitu tindakan pencabutan atau ekstraksi gigi. ${ }^{1}$

Riset Kesehatan Dasar (RISKESDAS) tahun 2010 menunjukkan bahwa masyarakat di Indonesia yang mendapat pelayanan ekstraksi gigi yaitu sebesar $79,6 \%{ }^{2}$ Di Sulawesi Utara gigi yang diekstraksi maupun indikasi ekstraksi gigi sebesar 4,34\%. ${ }^{3} \quad$ Angka-angka ini menunjukkan bahwa tindakan ekstraksi gigi merupakan tindakan yang banyak dilakukan.

Tindakan ekstraksi gigi merupakan cara termudah dan terbaik untuk menghilangkan sakit gigi, apabila gigi tersebut tidak dapat dipertahankan lagi. Disamping itu tindakan ekstraksi gigi juga merupakan salah satu jenis tindakan yang memiliki risiko tinggi dalam penularan infeksi. Infeksi merupakan bahaya yang sangat nyata pada lingkungan kedokteran gigi. Bidang kerja kedokteran gigi yang tidak lepas dari kemungkinan untuk berkontak langsung atau tidak langsung dengan mikroorganisme dalam rongga mulut pasien, menyebabkan pengendalian infeksi dibutuhkan dalam berbagai tindakan perawatan di bidang kedokteran gigi termasuk tindakan ekstraksi gigi. ${ }^{4}$ Berbagai infeksi dapat ditularkan melalui tindakan perawatan gigi, seperti berbagai infeksi virus, bakteri, jamur dan sebagainya. Masih tingginya angka penyakit infeksi virus hepatitis B serta semakin meningkatnya infeksi Humman Immunodeficiency Virus Acquired Immune Deficiency Syndrome (HIV/AIDS) yang ditularkan melalui darah dan saliva dari pasien menunjukkan bahwa penyakit-penyakit ini perlu diwaspadai. ${ }^{5}$

Penelitian yang dilakukan oleh American Dental Association (ADA) menunjukkan bahwa penularan penyakit hepatitis B terhadap tenaga kesehatan khususnya dokter gigi yang tidak diimunisasi mempunyai risiko enam kali lebih besar dari populasi umum di Amerika Serikat yaitu sebesar 76\%. ${ }^{4}$ Sedangkan penularan HIV lewat tranfusi darah/produk darah yang tercemar risikonya sangat tinggi sampai 90\% dan ditemukan sekitar 3-5\% dari total kasus sedunia. ${ }^{6}$

Di Indonesia di RSU pendidikan, infeksi silang cukup tinggi yaitu 6-16\% dengan rata-rata 9,8\%. Terdapat risiko yang sangat tinggi bagi dokter gigi untuk terkena infeksi silang dalam melakukan tindakan ektraksi gigi karena dapat berkontak langsung dengan darah, saliva dan alat-alat yang terkontaminasi. ${ }^{7}$

Alasan-alasan inilah yang mendasari peneliti untuk meneliti tentang pengendalian infeksi silang pada tindakan ekstraksi gigi. Penulis memilih RSGM Unsrat Manado sebagai lokasi penelitian, karena penelitian serupa belum pernah dilakukan di lokasi ini. Di samping itu dari survei awal yang dilakukan, penulis mendapati banyak tindakan yang dilakukan dengan mengabaikan prinsip-prinsip aseptis. Alasan lainnya yakni lokasinya mudah dijangkau sehingga efisien dari segi biaya dan waktu.

\section{BAHAN DAN METODE PENELITIAN}

Penelitian ini menggunakan metode deskriptif observasional dengan desain potong lintang. Penelitian ini dilaksanakan di Bagian Bedah Mulut Rumah Sakit Gigi dan Mulut PSPDG FK Unsrat pada bulan Februari - Oktober 2015. Jumlah sampel yang diteliti sebanyak 44 orang diperoleh dengan teknik purposive sampling.

Peneliti melakukan observasi pada operator dimulai dari sebelum tindakan, selama tindakan dan paska tindakan ekstraksi gigi dengan menggunakan lembar check list. Setelah diperoleh semua data yang diperlukan, data diolah secara manual dan disajikan berdasarkan distribusi frekuensi dalam bentuk Tabel.

\section{HASIL PENELITIAN}

Penelitian ini dilaksanakan di Bagian Bedah Mulut RSGMP PSPDG FK Unsrat 
pada bulan Juli 2015 dengan sampel penelitian berjumlah 44 orang yang

merupakan operator pada tindakan ekstraksi gigi.

1. Pencegahan dan pengendalian infeksi silang pra tindakan ekstraksi gigi

Tabel 1. Distribusi frekuensi perlindungan pribadi operator pra tindakan ekstraksi gigi

\begin{tabular}{|c|c|c|c|c|}
\hline \multirow{2}{*}{ Bentuk Perlindungan Pribadi } & \multicolumn{2}{|c|}{ Ya } & \multicolumn{2}{|c|}{ Tidak } \\
\hline & $\mathrm{n}$ & $\%$ & $\mathrm{n}$ & $\%$ \\
\hline Imunisasi : & & & & \\
\hline Vaksinasi hepatitis B bagi operator & 19 & 43,18 & 25 & 56,82 \\
\hline Teknik barrier praktis : & & & & \\
\hline $\begin{array}{l}\text { Mencuci tangan sebelum memakai } \\
\text { sarung tangan }\end{array}$ & 0 & 0 & 44 & 100 \\
\hline Memakai sarung tangan & 44 & 100 & 0 & 0 \\
\hline Memakai sarung tangan bedah steril & 0 & 0 & 44 & 100 \\
\hline Memakai masker & 44 & 100 & 0 & 0 \\
\hline Memakai kacamata pelindung & 0 & 0 & 44 & 100 \\
\hline Memakai pakaian pelindung/baju kerja & 44 & 100 & 0 & 0 \\
\hline Memakai sepatu tertutup & 17 & 38,64 & 27 & 61,36 \\
\hline Rerata & 21 & 47,75 & 23 & 52,25 \\
\hline
\end{tabular}

Tabel 2. Distribusi frekuensi tindakan sterilisasi instrumen pra tindakan ekstraksi gigi

\begin{tabular}{|c|c|c|c|c|}
\hline \multirow{2}{*}{ Tindakan sterilisasi } & \multicolumn{2}{|c|}{ Ya } & \multicolumn{2}{|c|}{ Tidak } \\
\hline & $\mathrm{n}$ & $\%$ & $\mathrm{n}$ & $\%$ \\
\hline \multicolumn{5}{|l|}{$\begin{array}{l}\text { Sterilisasi hand instrumen (set instrument } \\
\text { bedah minor) }\end{array}$} \\
\hline & 44 & 100 & 0 & 0 \\
\hline Sterilisasi henpis dan mata bur & 0 & 0 & 44 & 100 \\
\hline Rerata & 22 & 50 & 22 & 50 \\
\hline
\end{tabular}

\section{BAHASAN}

Pada penelitian ini diperolah hasil perlindungan pribadi operator pada pra tindakan ekstraksi gigi menunjukkan, operator yang sudah di vaksinasi Hepatitis B sebelum masuk coass hanya sebanyak $43,18 \%$ dan lebih besar jumlah operator (56,82\%) yang belum divaksinasi Hepatitis B. Hal ini menunjukkan bahwa masih kurangnya kesadaran operator yang adalah calon dokter gigi untuk memproteksi dirinya. Kurangnya kesadaran ini bisa disebabkan oleh kurangnya pengetahuan operator berkaitan dengan penyakit Hepatitis B ini, asumsi penulis apabila responden telah paham dengan penyakit ini dan dampaknya bagi kesehatan maka responden akan dengan sadar melakukannya. Vaksinasi Hepatitis B sangat direkomendasikan bagi setiap petugas kesehatan gigi. Hal ini sejalan dengan penelitian yang dilakukan oleh 
Suleh, Wowor, Mintjelungan: Pencegahan dan pengendalian...

Saheeb, Offor dan Okojie bahwa yang melakukan vaksinasi Hepatitis B sebelum pernah divaksinasi hepatitis B yaitu masuk coass yaitu $(22,1 \%)$ dan yang belum

$$
(88,9 \%){ }^{8}
$$

Tabel 3. Distribusi frekuensi tindakan desinfeksi permukaan kerja pra tindakan ekstraksi gigi

\begin{tabular}{|c|c|c|c|c|}
\hline \multirow{2}{*}{ Tindakan desinfeksi } & \multicolumn{2}{|c|}{ Ya } & \multicolumn{2}{|c|}{ Tidak } \\
\hline & $\mathrm{n}$ & $\%$ & $\mathrm{n}$ & $\%$ \\
\hline Pegangan lampu & 0 & 0 & 44 & 100 \\
\hline Tombol kursi & 0 & 0 & 44 & 100 \\
\hline Sandaran kepala & 0 & 0 & 44 & 100 \\
\hline Selang henpis & 0 & 0 & 44 & 100 \\
\hline Unit kontrol & 0 & 0 & 44 & 100 \\
\hline Tombol semprit air-udara & 0 & 0 & 44 & 100 \\
\hline Meja instrumen & 44 & 100 & 0 & 0 \\
\hline & 6,28 & 14,28 & 37,72 & 85,72 \\
\hline
\end{tabular}

2. Pencegahan dan pengendalian infeksi silang pra tindakan ekstraksi gigi

Tabel 4. Distribusi frekuensi pencegahan dan pengendalian selama tindakan ekstraksi gigi

\begin{tabular}{|c|c|c|c|c|}
\hline \multirow{2}{*}{ Tindakan pencegahan dan pengendalian } & \multicolumn{2}{|c|}{ Ya } & \multicolumn{2}{|c|}{ Tidak } \\
\hline & $\mathrm{n}$ & $\%$ & $\mathrm{n}$ & $\%$ \\
\hline Tindakan asepsis pada pasien: & & & & \\
\hline Berkumur dengan larutan antimikrobial & 0 & 0 & 44 & 100 \\
\hline $\begin{array}{l}\text { Pemberian desinfektan sebelum insersi } \\
\text { jarum suntik }\end{array}$ & 44 & 100 & 0 & 0 \\
\hline $\begin{array}{l}\text { Tindakan pencegahan kecelakaan kerja: } \\
\text { Jarum suntik ditutup setelah tindakan } \\
\text { anestesi }\end{array}$ & 44 & 100 & 0 & 0 \\
\hline $\begin{array}{l}\text { Penutupan jarum suntik dengan teknik satu } \\
\text { tangan }\end{array}$ & 12 & 27,27 & 32 & 72,37 \\
\hline $\begin{array}{l}\text { Menghindari tertusuk instrumen dan jarum } \\
\text { yang tajam }\end{array}$ & 44 & 100 & 0 & 0 \\
\hline $\begin{array}{l}\text { Tindakan pencegahan penularan infeksi } \\
\text { melalui operator: } \\
\text { Tangan operator tidak menyentuh }\end{array}$ & & & & \\
\hline lingkungan kerja/peralatan yang tidak steril & 15 & 34,09 & 29 & 65,91 \\
\hline Rerata & 26,5 & 60,26 & 17,5 & 39,74 \\
\hline
\end{tabular}


3. Pencegahan dan pengendalian infeksi silang selama tindakan ekstraksi gigi

Tabel 5. Distribusi frekuensi pencegahan dan pengendalian paska tindakan ekstraksi gigi

\begin{tabular}{|c|c|c|c|c|}
\hline \multirow{2}{*}{$\begin{array}{c}\text { Pencegahan dan pengendalian paska tindakan } \\
\text { ekstraksi gigi }\end{array}$} & \multicolumn{2}{|c|}{ Ya } & \multicolumn{2}{|c|}{ Tidak } \\
\hline & $\mathrm{n}$ & $\%$ & $\mathrm{n}$ & $\%$ \\
\hline Perlindungan pribadi : & & & & \\
\hline $\begin{array}{l}\text { Mencuci tangan asepsis setelah sarung tangan } \\
\text { dibuka }\end{array}$ & 0 & 0 & 44 & 100 \\
\hline $\begin{array}{l}\text { Menggunakan sarung tangan kerja dari karet } \\
\text { tebal sebelum mencuci instrumen bekas pakai }\end{array}$ & 0 & 0 & 44 & 100 \\
\hline Penanganan instrumen bekas pakai: & & & & \\
\hline $\begin{array}{l}\text { Pemindahan baki instrumen dari daerah kerja } \\
\text { ke daerah dekontaminasi dalam keadaan } \\
\text { tertutup }\end{array}$ & 8 & 18,18 & 36 & 81,82 \\
\hline $\begin{array}{l}\text { Pemindahan instrumen yang terkontaminasi } \\
\text { tidak melewati daerah yang steril }\end{array}$ & 0 & 0 & 44 & 100 \\
\hline $\begin{array}{l}\text { Pembersihan instrumen bekas pakai dengan } \\
\text { air, sikat dan deterjen. }\end{array}$ & 44 & 100 & 0 & 0 \\
\hline Sterilisasi instrumen bekas pakai & 44 & 100 & 0 & 0 \\
\hline $\begin{array}{l}\text { Penanganan sampah medis bekas praktek: } \\
\text { Menempatkan sampah infeksius pada } \\
\text { kontainer yang tepat yaitu tahan bocor dan } \\
\text { warna kuning }\end{array}$ & 36 & 81,82 & 8 & 18,18 \\
\hline $\begin{array}{l}\text { Menempatkan sampah non infeksius pada } \\
\text { kontainer warna hitam }\end{array}$ & 34 & 77,27 & 10 & 22,72 \\
\hline Rerata & 20,75 & 47,16 & 23,25 & 52,84 \\
\hline
\end{tabular}

Tabel 6. Distribusi frekuensi pencegahan dan pengendalian infeksi silang pra tindakan, selama tindakan dan paska tindakan ekstraksi gigi

\begin{tabular}{lcc}
\hline \multicolumn{1}{c}{ Pencegahan dan pengendalian infeksi silang pra } & Ya & Tidak \\
\cline { 2 - 3 } \multicolumn{1}{c}{ tindakan selama tindakan dan paska ekstraksi gigi } & $\%$ & $\%$ \\
\hline Pra tindakan ekstraksi gigi & 37,4 & 62,6 \\
Selama tindakan ekstraksi gigi & 60,26 & 39,74 \\
Paska tindakan ekstraksi gigi & 47,16 & 52,84 \\
\hline
\end{tabular}

Perlindungan diri dengan teknik barrier praktis menunjukkan semua operator (100\%) memakai sarung tangan, memakai masker dan memakai pakaian pelindung/baju kerja. Sarung tangan yang dipakai adalah sarung tangan periksa yang terbuat dari bahan vinil yang biasa dipakai untuk pemeriksaan singkat dengan risiko paparan rendah. Kurangnya pemahaman responden bahwa penggunaan sarung tangan yang tipis dan mudah robek merupakan faktor risiko terhadap penularan infeksi saat melakukan tindakan ekstraksi gigi antara lain menggambarkan tingkatan 
pengetahuan yang dimiliki operator dalam tindakan pencegahan dan pengendalian infeksi di bidang kedokteran gigi. Saat melakukan tindakan ekstraksi gigi, operator seharusnya menggunakan sarung tangan bedah berupa sarung tangan lateks yang memberikan perlindungan terbaik untuk tindakan bedah termasuk tindakan ekstraksi gigi yang beresiko tinggi terhadap paparan darah atau cairan tubuh yang potensial terkontaminasi. $^{9}$

Hasil penelitian selanjutnya menunjukkan semua operator (100\%) memakai masker, namun masker yang dipakai adalah masker dari bahan katun dan kertas. Masker ini nyaman digunakan tetapi sebagai filter memiliki sifat tidak tahan cairan sehingga kurang efektif. Operator harus memakai masker respirator yaitu masker jenis khusus, yang dianjurkan untuk memfilter udara yang masuk saat menarik nafas. Penggunaan masker jenis ini dianggap sangat penting karena terdiri dari bahan filter yang berlapis-lapis yang terpasang pada muka dengan ketat. Pemakaian masker ini agak menyebabkan kurang nyaman saat bernapas dan sangat mahal harganya. Mungkin dengan alasan ini operator tidak pernah memakai masker tersebut. $^{9}$

Pada pemakaian pakaian pelindung, semua operator (100\%) memakainya, namun pakaian pelindung yang dipakai diganti 3 hari sekali, bahkan ada yang mengganti pakaian pelindung seminggu sekali. Hal ini bisa dilihat dari pakaian pelindung yang dipakai berhari-hari warnanya sudah terlihat agak kecoklatan yang menandakan bahwa pakaian pelindung yang dipakai sudah kotor. Responden tidak menyadari percikan selama melakukan tindakan ekstraksi gigi dapat mengontaminasi pakaian yang digunakan setiap hari saat bekerja. Jumlah terendah ialah memakai sepatu tertutup yaitu $(38,64 \%)$ dan tidak memakai sepatu tertutup yaitu (61,36\%). Pemakaian sepatu tertutup merupakan salah satu tindakan pencegahan dan pengendalian yang dilakukan untuk mencegah adanya instrumen yang terjatuh dan tertusuk di kaki, kenyataannya responden sangat mengabaikan hal tersebut. Tidak pernah melakukan tindakan mencuci tangan sebelum memakai sarung tangan, tidak memakai sarung tanagan bedah steril, memakai kacamata pelindung yaitu (100\%).

Mencuci tangan sebelum memakai sarung tangan merupakan tindakan yang penting dilakukan, untuk mengilangkan kotoran dan debu secara mekanis dari permukaan kulit dan mengurangi jumlah mikroorganise sementara. Cuci tangan dengan sabun biasa dan air sama efektifnya dengan cuci tangan menggunakan sabun anti mikrobial. Sarung tangan bedah steril adalah sarung tangan yang elastis dan tidak mudah robek saat kita memakainya dan kacamata pelindung sangatlah penting dipakai untuk mengurangi percikan darah,saliva dari pasien. Kurangnya kenyamanan dalam memakai kacamata pelindung sehingga responden tidak ada yang memakainya.

Berdasarkan hasil frekuensi tindakan sterilisasi instrumen pra tindakan ekstraksi gigi menunjukkan (100\%) melakukan sterilisasi. Responden mengsterilkan instrumen dengan menggunakan autoclave, dikarenakan lebih mudah dan cepat dibandingkan menggunakan alat sterilisasi yang lain. Tindakan sterilisasi yang tidak pernah dilakukan adalah sterilisasi henpis dan bur (100\%), tindakan itu sangat berbahaya jika responden menggunakan henpis dan bur yang tidak steril akan memicu terjadinya infeksi silang di daerah lingkup kerja.

Berdasarkan hasil frekuensi tindakan desinfeksi permukaan kerja pra tindakan ekstraksi gigi menujukkan (100\%) melakukan desinfeksi pada meja instrumen. Responden hanya mengalas meja instrumen dengan kain putih atau tissue saja, seharusnya dibungkus dengan plastik disposibel agar tiap kali kerja responden dapat menggantikan dengan palstik yang baru. Kalau hanya menggunkan kain saja, itu tidak pernah di cuci atau ganti tiap kali kerja tapi dipakai dalam jangka waktu yang lama. Menggunakan tissue sudah lumayan 
baik, sekali pakai tapi belum maksimal karena tissue tidak dapat menutupi smua permukaan meja instrumen dibandingkan dengan pslatik disposibel dan 100\% tidak pernah menggunakan plastik disposibel untuk pegangan lampu, tombol kursi, sandaran kepala, selang henpis, unit kontrol dan tombol semprit air-udara. Hal ini sangat disayangkan sekali karena penutupan bagian-bagian tersebut sangat penting dilakukan, tidak hanya untuk alasan estetik, tetapi terutama karena desinfeksi yang efektif akan mengurangi kemungkinan terjadinya infeksi silang dari permukaan kerja. ${ }^{4}$

Berdasarkan frekuensi pengendalian infeksi silang selama tindakan ekstraksi gigi menunjukkan (100\%) melakukan tindakan asepsis sebelum insersi jarum suntik, jarum suntik ditutup setelah tindakan anestesi, penutupan jarum suntik dengan teknik satu tangan dan menghindari tertusuk instrumen dan jarum yang tajam. Tindakan desinfeksi sebelum insersi jarum suntik sudah dilakukan dengan baik menggunakan betadine yang di tetesi dikapas kemudian dioleskan pada daerah kerja di rongga mulut. Tindakan desinfeksi yang dilakukan untuk membebaskan kuman pada daerah kerja. Jarum suntik ditutup setelah tindakan menghindari tertusuk instrumen dan jarum suntik ditutup setelah tindakan anestesi, menunjukkan pengendalian infeksi silang sudah baik pada tindakan ini. Tangan operator yang tidak menyentuh lingkungan kerja/ peralatan yang tidak steril yaitu 34,09\% dan tidak melakukan ada 65,91\% Masih sangat kurang diperhatikan oleh operator bahwa tindakan tersebut dapat membahayakan operator dan pasien jika terkontaminasi. Penutupan jarum suntik dengan teknik satu tangan yaitu (27,27\%), dan yang tidak melakukan $72,37 \%$ mungkin responden tidak tahu kegunaan dari teknik tersebut untuk melindungi diri responden. Menghindari tertusuk dari instrumen dan jarum yang tajam sudah kelihatan baik, karena semua operator bekerja dengan penuh hati terhadap instrumen yang digunakan, dan tngan operator menyentuh lingkungan kerja/ peralatan yang tidak steril terlihat masih kurang juga, kemungkinan mereka masih belum paham atau sama sekali tidak tahu risiko-risiko infeksi silang dalam melakukan tindakan ekstraksi gigi. Pasien yang tidak berkumur dengan larutan antimikrobial sebelum tindakan yaitu 100\%, Tindakan ini terbukti dapat mengurangi jumlah mikroba rongga mulut sampai $90 \%$. Tapi sayangnya tindakan ini sama sekali tidak dilakukan. ${ }^{4}$

Hasil penelitian pengendalian infeksi silang paska tindakan ekstraksi gigi terbagi atas perlindungan pribadi, penanganan instrumen bekas pakai dan penanganan smapah medis bekas praktek. Distribusi pengendalian infeksi silang paska tindakan ekstraksi gigi menunjukkan (100\%) pembersihan isntrumen bekas pakai dengan (air, sikat, deterjen) dan sterilisasi instrumen. Pembersihan instrumen bekas pakai dan sterilisasi instrumen sudah dilakukan dengan baik. Pembuangan sampah medis bekas praktek infeksius pada tempat yang tepat yaitu (81,82\%) dan tidak menempatkan sampah pada tempat yang benar (18,18\%). Menempatkan sampah noninfeksius pada tempat sampah yang tepat yaitu $(77,27 \%)$ dan tidak menempatkan pada tempat yang tepat (22,72\%) Sebagian membuang sampah tidak sesuai pada tempatnya, ada yang membuang sampah infeksius pada tempat smpah non infeksius dan sebaliknya. Hal ini sangat membahayakan orang yang bertugas mengelola sampah kalau tidak hati-hati sangat besar kemungkinan terkontaminasi dengan sampah yang sudah tercampur yang tidak sesuai dengan tempatnya. Pada saat pemindahan baki instrumen dari daerah dekontaminasi dalam keadaan tertutup yaitu (18,18\%) dan tidak melakukan pemindahan baki instrumen secara tertutup (81,82\%), ini sangat bahaya sekali kalau membawah peralatan bekas pakai dengan keadaan terbuka, kalau ada instrumen yang jatuh mengenai bagian tubuh kita atau tertusuk akan menimbulkan infeksi silang. Tidak pernah dilakukan adalah mencuci tangan asepsis setelah 
tindakan $100 \%$, selesai tindakan operator hanya membuka sarung tangan tanpa mencuci tangan langsung menulis resep, mengambil obat dan lain-lain.

\section{SIMPULAN}

1. Pencegahan dan pengendalian infeksi silang pra tindakan ekstraksi gigi dilakukan sebesar 37,4\%.

2. Pencegahan dan pengendalian infeksi silang selama tindakan ekstraksi gigi dilakukan sebesar 60,26\%.

3. Pencegahan dan pengendalian infeksi silang paska tindakan ekstraksi gigi dilakukan sebesar 47,16\%.

4. Secara umum pencegahan dan pengendalian infeksi silang pada tindakan ekstraksi gigi di RSGM PSPDG FK Unsrat hanya dilakukan sebesar $48,23 \%$.

\section{SARAN}

1. Bagi masyarakat, dapat bersikap kritis terhadap mutu pelayanan kesehatan gigi dan mulut yang diberikan oleh instusi pelayanan dalam hal ini RSGM PSPDG FK Unsrat.

2. Bagi RSGM PSPDG FK Unsrat, diharapkan semua mahasiswa profesi yang merupakan calon dokter gigi dapat melakukan pencegahan dan pengendalian infeksi silang dengan maksimal.

3. Diharapkan penelitian lanjut yang sejenis dengan populasi yang lebih besar sehingga dapat diperoleh hasil yang akurat dan bisa dimanfaatkan.

\section{DAFTAR PUSTAKA}

1. Amir A, Hanafiah JM. Etika Kedokteran dan Hukum Kesehatan. Jakarta: EGC, 2014.

2. Badan Penelitian dan Pengembangan Kesehatan RI. Laporan Hasil Kesehatan Dasar (RISKESDAS) Jakarta, 2010.

3. Badan Penelitian dan Pengembangan Kesehatan RI. Laporan Hasil Riset Kesehatan Dasar (RISKESDAS) Jakarta, 2007.

4. Cottone, Terezhalmy, Molinari. Mengendalikan Penyebaran Infeksi pada Praktik Dokter Gigi. Jakarta: Widya Medika, 2000.

5. Wibiwo T, Parisihni K, Haryanto $D$. Proteksi Dokter Gigi Sebagai Pemutus Rantai Infeksi Silang. Jurnal PDGI. 2009;58(2).

6. Notoadmodjo. Kesehatan Masyarakat (Ilmu dan Seni). Jakarta: Rineka Cipta, 2007.

7. Saleh M, Rares SEF, Soeliongan S. Pola Bakteri Aerob Penyebab Infeksi Nosokomial pada Ruangan Neonatal Intensive Care Unit (NICU) BLU RSUP Prof. Dr.. R.D. Kandou Manado. e-Bm;2015;3(1).

8. Setiawan IP. Tingkat Kepatuhan Mahasiswa Coass Terhadap Standar Operasional Prosedur Dalam Pengendalian Infeksi Silang Di RSGM Hj. Halima. Dg. Sikati JL. Kandea Kota Makasar [Skripsi]. Makassar: Unhas; 2014.

9. Panduan Pencegahan Infeksi Untuk Fasilitas Kesehatan Dengan Sumber Daya terbatas. Jakarta, 2004. 